\title{
A Labor Day Warning
}

Today is Labor Day, a public holiday honoring the American labor movement and the contributions that workers have made to the strength, prosperity, laws, and well-being of the country. Though this holiday dates back to the end of the nineteenth century, the concept of organized labor is under increasing attack. While many of the physician and nurse readers may think that "labor" does not apply to them, after all they are professionals, management would likely disagree.

In Arizona v. Maricopa County Medical Society in 1982, the Supreme Court ruled that when physicians negotiate collectively with insurers about fees, and as a consequence do not compete with one another, such negotiations represent a horizontal agreement among competitors to fix prices (1). This was based on the concept of physicians being independent from hospitals or healthcare systems. However, more physicians are now hospital employed which has been in no small part due to cuts in physician compensation by Medicare with the insurers rapidly following. This increase in physician employment has been associated with increased billings leading to increased profits and decreased physician compensation $(2,3)$.

The Nation's largest healthcare system is the Department of Veterans Affairs (VA). The pace of VA hiring has not kept pace with the growth of patients leading to prolonged wait times first reported in Phoenix (4). Two recent decisions will likely affect physician hiring and retention at the VA. First, President Trump announced cancellation of the the planned salary increase for civilian employees (5). Second, VA Secretary Robert Wilkie, cancelled collective bargaining rights when it comes to professional conduct and patient care by VA providers (6). In the private sector, hospital employed physicians seem to becoming increasingly discontented because of 1 . Having to deal with a lot of rules; 2 . Having to deal with a large bureaucracy. 3 . Not having a staff under their control; and 4. Having little control over compensation models (7).

All in all, this does not bode well for physicians or patients. The data suggest that the Medicare has helped destroy independently employed physicians while over compensating hospital employed physicians whose fees are collected by the hospital (7). This trend will likely continue until Medicare realizes that the existence of the independent practitioner keeps healthcare costs down. By financially squeezing the independent practitioner Medicare's actions lead to decreased competition and increased healthcare costs.

Richard A. Robbins, MD Editor, SWJPCC

\section{References}

1. Halper HR. Arizona v. Maricopa County: a stern antitrust warning to healthcare providers. Healthc Financ Manage. 1982 Oct;36(10):38-42. [PubMed] 
2. Lowes R. Hospital-employed physicians cost Medicare more, study says. Medscape. November 16, 2017. Available at: https://www.medscape.com/viewarticle/888772\#vp 1 (accessed 9/3/18).

3. Kane L. Medscape physician compensation report 2018. Medscape. April 11, 2018. Available at: https://www.medscape.com/slideshow/2018-compensation-overview6009667\#12 (accessed 9/3/18).

4. Davidson J. VA doctor shortage fueled by management issues, poor pay The Washington Post. July 16, 2018. Available at:

https://www.washingtonpost.com/news/powerpost/wp/2018/07/16/va-doctorshortage-fueled-by-management-issues-poor-pay/?utm term=.070275d06e2a (accessed 9/3/18).

5. Liptak K. Trump cancels pay raises for federal employees. CNN. August 31, 2018. Available at: https://www.cnn.com/2018/08/30/politics/trump-cancels-federalemployee-pay-raises/index.html (accessed 9/3/18).

6. Department of Veterans Affairs. VA secretary clarifies collective bargaining authority for patient care. August 29, 2018. Available at:

https://www.managedhealthcareconnect.com/content/va-secretary-clarifiescollective-bargaining-authority-patientcare? hmpid=cmlja3JvYmJpbnNAY294Lm5IdA== (accessed 9/3/18).

7. Mertz GJ. Physicians employed by hospitals. Medscape. January 01, 2018. Available at: https://www.medscape.com/viewarticle/891120\#vp 1 (accessed $9 / 3 / 18)$.

8. Lowes R. Hospital-employed physicians cost medicare more, study says. Medscape. November 16, 2017. Available at: https://www.medscape.com/viewarticle/888772 (accessed 9/3/18). 